\title{
Shakespeare as a Secularist in Bingo
}

\author{
Yan-Hua Xia ${ }^{1,2}$ \\ ${ }^{1}$ School of Foreign Languages, China West Normal University, China \\ ${ }^{2}$ School for Foreign Studies, University of Science and Technology Beijing, China \\ Correspondence: Yan-Hua Xia, School of Foreign Languages, China West Normal University, $1^{\#}$ Shida Road, \\ Shunqing District, Nanchong 637009, Sichuan Province, China. E-mail: philipxiayanhua@126.com
}

Received: March 4, 2014 Accepted: April 15, 2014 Online Published: May 27, 2014

doi:10.5539/ells.v4n2p51 URL: http://dx.doi.org/10.5539/ells.v4n2p51

\begin{abstract}
Edward Bond's historical play Bingo, written in 1973, dramatically depicts Shakespeare as an exploiter and a suicide. It has given rise to lasting arguments in western academia ever since its première. Based on the focus of the disputes since the 1970s and the historical background of the enclosure movement, the characterization of this play is asserted through analyzing Shakespeare's ethical dilemma in terms of his handling of financial temptation, family indifference and literary infertility from the perspective of ethical literary criticism. The play's "alienation effect" and the tension of ethical interpretation generated by it are further discussed. By virtue of the above analysis, this paper advances a defense of Bond's adoption of new historicism in writing.
\end{abstract}

Keywords: Shakespeare, Edward Bond, Bingo, ethical knot, alienation

\section{Introduction}

Born in 1934, Edward Bond emerged as a playwright as part of what is entitled as the "New Wave of British Theatre" catalyzed by John Osborne's Look Back in Anger in 1956. He is often mentioned in the same breath as John Osborne (1929-1994), Arnold Wesker (1932- ) and Harold Pinter (1930-2008). His success, like that of his peers, owes much to the encouragement of new talent by the English Stage Company at the Royal Court Theater. His historical play Bingo: Scenes of Money and Death (here after "Bingo" for short), directed by Jane Howell and John Dove, was first presented at the Northcott Theatre, Devon on 14 November 1973. By this time Bond had already become a publicly recognized playwright like his peers, and his earlier plays, The Pope's Wedding (1962), Saved (1965), Early Morning (1967), and The Sea (1973), had been widely praised. However, Bingo did not achieve the same instant critical approval as his earlier plays. Simon Trussler, Benedict Nightingale, Jenny S. Spencer and some others all expressed their doubts about it. From 1973 to 2012, the play only gradually won the attention and approval it deserves. The reasons for this are worthy of a detailed discussion, and this discussion can undoubtedly lead us into a further discussion of this play from the perspective of "ethical literary criticism" and its alienation effect.

\section{Bingo: An Argumentative Historical Play}

Bingo is set in early 17th-century England in the transitional period from feudalism to capitalism, at a time of social unrest partly caused by the Enclosure Movement and the rise of the Protestant religion. The play depicts an ageing William Shakespeare in jumping plot at his Warwickshire home during the last months of his life (in 1615 and 1616). According to Bond, it is based on the famous Shakespeare expert E. K. Chambers' work on the Welcombe enclosure, notes about the enclosure saved by Shakespeare's cousin, Thomas Greene, and other well documented facts about the early $17^{\text {th }}$ century England. It's a historical play with evidence from some legal and financial documents of the time. This factual basis of the play is mentioned in the preface of Bingo, in which Bond writes:

"A large part of his income came from rents (or tithes) paid on common fields at Welcombe near Stratford. Some important landowners wanted to enclose these fields ... and there was a risk that the enclosure would affect Shakespeare's rents. He could either side with the landowners or with the poor who would lose their land and livelihood. He sided with the landowners. They gave him a guarantee against loss, and this is not a neutral document because it implies that should the people fighting the enclosures come to him for help he would refuse it. Well, the town did write to him for help and he did nothing." (Bond, 1987, p. 6) 
In the play, William Combe, a landowner and stapler wool man, seeks larger profits by enclosing land, thereby stripping the tenant farmers of land they have rented. It is he who persuaded Shakespeare to sign the contract of transferring the rent of his land into his hand. Shakespeare is dramatized as a kind old man suffering pangs of conscience because he reaches an agreement with Mr. Combe, by which his own financial interests will be protected on condition that he does not side with the farmers. Bond imaginatively and surprisingly portrays the great dramatist who is our revered and greatest playwright, describing him as a tormented figure driven to self-destruction.

However, both Bond's factual claims and creative imagination were not well-received by either audience or critics when the play premiered in 1973. The former found it unbearable to accept the much revered playwright as an exploiter and a self-slayer. Bond's boldness and originality were blasphemy again a semi-divine figure and the whole play was regarded as a parody. As for the critics, Simon Trussler reviewed it with comments like "less densely structured" (Trussler, 1976, p. 31), "Bond's intentions are too far out of consonance with what is actually happening on stage ... it elaborates commonplace sentiment" (Trussler, 1976, p. 32). Jenny S. Spencer recalled "the subject-matter and its treatment left audiences "cold"" (Spencer, 1992, p. 44). Benedict Nightingale compared it with Early Morning and said: "A despairing, disgusted suicide seems scarcely less historically credible than a lesbian love-affair between Queen Victoria and Florence Nightingale" (Nightingale, 1973, p. 783).

Even when its revival at the Young Vic Theatre, opening Feb. 16, 2012, directed by Angus Jackson, with a cast led by Patrick Stewart (Shakespeare), John McEnery (Old Man), Catherine Cusack (Judith) and Richard McCabe (Ben Jonson), was treated quite favorably by many critics such as Sheila Connor, Michael Billington, Steve Clayton, etc., the nonconformist Peter Brown only praised it to the extent of saying "the second half starts with much more energy and zip with the appearance of the mercurial poet, actor and dramatist Ben Johnson" (Brow, 2012), but still denied it was a riveting play "because the first half is rather pedestrian, brooding and contemplative" (Brow, 2012).

The disputes on Bingo have lasted 39 years and are likely to continue for many more. It can be positively concluded that all these disputes have not devalued this play but rather helped to prolong its vitality. A play which has no capacity to stir up lasting controversy is not a play for all time. Shakespeare himself is deathless because his profound insight into the human condition is worthy of discussing so long as men can breathe and mouths can talk, and James Joyce has become a classic because the ambiguous last four chapters of Ulysses attract everlasting academic debate and rethinking. With every cycle of stage production and on-going argument, Bond's Bingo has also evolved into a young classic. With other of his works treated in the same way throughout Europe and America, Bond himself has undoubtedly been recognized as an evergreen tree in the modern theater.

\section{Ethical Literary Criticism: A Possible New Approach to Study Bingo}

As is observed above, the aspect of Bingo which is most hard to accept is that Shakespeare is depicted as an exploiter and a self-slayer. Is this new portrayal of Shakespeare a parody, an awkward design or a careful and meticulous creation? Since the key disputes are about the moral and ethical elements of the play rather than its performance effect in the theater, the theory of ethical literary criticism which emphasizes the dialectical study of morality, ethics and history in literature can be of help to judge the rationality of Shakespeare's suicide.

Ethical literary criticism, first proposed by the Chinese scholar Nie Zhenzhao in 2004, is a new theoretical approach to the study of literature. It developed out of "ethical criticism", which was commonly used by western sociologists to study the ethical relations and moral phenomena of a given society in the 1980s in relation to the criticism of fictional literary works. It is in essence a kind of moral criticism, which makes judgment on the literary works of any age according to the moral principles generally accepted by the time to which that piece of work refers. Because different times have different values and ethical beliefs, ethical literary criticism has nothing to do with the moral principles of a critic's time. Instead,

"It requires a critic to go back to the historical moment at which the fictional world of a literary work was built to study the ethical factors which bring about the change of the fate of a character or the change of a historical direction. Ethical literary criticism seeks to interpret the behaviors of characters, human relationship, social happenings, etc. from the perspective of ethics and make moral judgments from the viewpoint of the history in which a story happens." (Nie, 2010, p. 14)

With regard to contemporary literature, ethical literary criticism studies it in relation to contemporary moral principles. It not only provides a moral study of the fictional society in the literature but also requires study of the relationship between the fictional society of the literary work and the historical realities of that time. So "ethical criticism" and "ethical literary criticism" do share some similarities, but they are actually different. 
Because it has proved so applicable to texts of all kinds, the theory of ethical literary criticism has stirred up a great deal of sharp discussion and increasingly become a widely acknowledged new critical theory. Within eight years of its birth, more and more Chinese scholars have begun to adopt it to the study of literature. Why has this theory spread so quickly in Chinese academia? Its core idea shows that it is deeply rooted in the literary critical tradition of China. "The corner stone of ancient Chinese literary criticism is 'the literary view of civil education' set by the Confucianists" (Guo, 2000, p. 55). "The literary view of civil education" was formed during the Han Dynasty nearly 1800 years ago, which basically holds that music and poetry are essentially carriers of certain ethical and moral values. Because of this, feudal kings were able to use them as instruments to teach the grass roots what was right and wrong through mingling prescribed ethical beliefs with the beauty of poetry and music, and the ultimate purpose of this teaching was to enhance the rule of the feudal kings. "Through the teaching of poetry and music, both people's thoughts and behaviors could be cultivated and they would accordingly become better citizens rather than a mob" (Guo, 2000, p. 52).

The Literary Mind and the Carving of Dragons (Note 1), completed approximately in 501-502 A. D., also has some discussion about the changing nature of literary trends which is very similar to Nie's idea embedded in ethical literary criticism. The $45^{\text {th }}$ chapter, "Literature and Times," reads: "The times alternate and change, the preference of literature style changes accordingly. The old reason and the new reason, it's hard to judge which one is correct" (in Chinese: 时运交移, 质文代变, 古今情理, 如可言乎? ) (Liu, 2011, p. 92). The chapter ends with:

"With the passage of ten dynasties,

Literary trends have changed nine times.

When the pivot moves,

Changes occur."

(in Chinese: 蔚映十代, 辞采九变。枢中所动, 环流无倦。) (Liu, 2011, p. 94)

According to Liu's further discussion in this chapter, his idea of "literary trends" is inclusive. It contains not only the types and forms of literature, language styles, but also the ethical and moral ideas of literary works. He lists three causes which brought changes of literary style. The foremost of these is the need to depend on literature to give ethical and moral education to the broad masses. The rulers of different dynasties have their own ethical and moral expectations of the masses different from those of former dynasties, so the ethical values of literature will change with the change of dynasties.

We can turn our attention from ancient Chinese literary critics to Chinese writers for further proof of this viewpoint. Mo Yan, the first Chinese Nobel laureate for literature, recently gave a lecture at Stockholm University. In the lecture, he said that, as "the ultimate purpose of all literature is to explore humanity, and ethical values in humanity are complex and contradictory, he would try to create more paradoxical figures in future writing" (Note 2). Jin Yong, another great contemporary Chinese author of many novels, once wrote in the preface of a collection of his works:

"Historical figures should be judged by putting them back into their own historical time. What my novels describe are historical ethical values and psyches which cannot be weighed by modern values. My purpose of writing novels is to depict humanity and portray the passions of joy, anger, sorrow and happiness in human nature. Novels don't give insinuate anything. If a novel does intend to criticize something, it must be the dark side of human nature." (Jin, 1994, p. II)

From their comments, both Chinese authors have emphasized the close relationship between literature and ethical values. Jin Yong especially points out the changing nature of ethical values, taking a position which is almost identical with Nie's.

The discussion above proves that Nie's proposal of this new theory derives from the long literary tradition of China rather than being made out of whole cloth or pure speculation. In the age of globalization, many western critical theories have been applied to the study of Chinese literature, which has enlarged Chinese scholars' academic vision, offered more methodologies and accordingly contributed to some unexpected and remarkable achievements. Can this also be true in reverse if we use ethical literary criticism to look into Shakespeare's choice of suicide in Bingo? In talking about his own motives in writing problem drama, Bond once said, "I would not just like to state a problem in bare terms. I always think one wants at the very least to imply certain moral values, or intellectual values" (Gordon, 1966, p. 418). As he has said, Bond has put moral issues and ethical themes related to money, sympathy, family bliss, suicide, etc. in this play. So it is worth a try. 


\section{Reading Bingo from the Perspective of Ethical Literary Criticism}

Shakespeare's suicide of this play is the most controversial point with audience and critics. Bond's arrangement of the plot concludes that Shakespeare, such a great figure, has no ability to take control of his life. His choice of death comes from disillusionment with his expectation of enjoying living a serene and contented retirement. He decides to die early rather than remain in a helpless condition. Looking at it from the perspective of ethical literary criticism, the reason for his choice of suicide is because he is strangled in an ethical knot which he cannot himself untie. His dilemma is so complex that it can be viewed from at least three angles, i.e., his multiple suffering from ethical confusions in finance, family bonds and the decline of his powers as an imaginative writer. They are the three ethical threads which make up the ethical knot.

Shakespeare's first ethical confusion comes from money matters. The play starts with the historical background of the enclosure movement. When the local landowner William Combe comes to Shakespeare to enlist his support in the enclosure of the common fields from the hands of the tenant farmers, Shakespeare's chief concern is to protect his profits. "I bought my share years ago out of money I made by writing. ... I wanted security" (Bond, 1987, p. 19). The retired Shakespeare wants regular income, so he agrees to keep silent so long as his own profit is assured by Mr. Combe. However, he is not a completely money-minded man. To some degree, his decision to sign the agreement with Mr. Combe was not out of his personal intention but one in which he was following the norms dictated by the historical period in which he was living.

England's period of transition from feudalism to capitalism led people of that age to act according to the principle of self-interest. Shakespeare was just one of them. Although he was unable to render them justice, his sympathy for the tenant farmers is shown by his offering of pecuniary aid to the young vagrant woman roaming to his garden. She is the young daughter of a tenant family who lost their land in the enclosure movement. William Combe threatens and whips her for her illegal entry into a prohibited area. Compared with Combe's cruelty and malice, Shakespeare feels quite sympathetic toward the girl. However, he can do nothing but to give her some money and let her go. Shakespeare's agreement with Mr. Combe and his giving alms to the vagrant woman are paradoxical and call into question his consciousness of his self, thereby creating his first ethical confusion.

The lack of concordance between literary greatness and domestic bliss is the second ethical confusion Shakespeare encounters. In the play, there are altogether two persons acting as Shakespeare's family, his daughter Judith and his wife. But like his servants, his wife is portrayed as a pitiful woman who doesn't even have a name and is not given a single line to speak. Bond makes her a bedridden woman whom Shakespeare doesn't even want to go and visit. He always sits in the garden, mostly in silence, alienated from his wife, entirely unmindful of her illness. Seeing her father showing his kindness to a stranger, Judith is not satisfied with his unfair treatment of her mother, so she constantly strikes a discordant note with her father.

In Scene Two, when Shakespeare asks his daughter Judith to give the shaking young woman a shawl or a dress no longer used by her mother to protect her from the cold, she refuses to obey him and warns: "No. If we feed her once we'll never get rid of her ... She'd steal if we had her here, the poor thing" (Bond, 1987, pp. 28, 29). She even urges him to leave the family:

"Why are you so stubborn? Your family's tearing itself to bits and you sit in the garden. ... If we bore you why don't you go away, father? Go back to your interesting friends." (Bond, 1987, p. 34)

Later in Scene Five, from the dialogue between Shakespeare and Judith, we can learn the causes of his indifference to his family:

"When I ran away from your mother and went to London-I was so bored, she's such a silly woman, obstinate, and you take after her. Forgive me, I know that's cruel, sordid, but it's such and effort to be polite any more. That other age when I ran away, I couldn't cut you out, you were my flesh, but I thought I could make you forgive me: I started to collect for you. I loved you with money. The only thing I can afford to give you now is money. But money always turns to hate. If I tried to be nice to you now it would be sentimental. You'd have to understand why I hate you, respect me for it, even love me for it. How can you? I treated you so badly. I made you vulgar and ugly and cheap. I corrupted you.” (Bond, 1987, pp. 55, 56)

These lines disclose Shakespeare's early unhappy marriage in his home town and the reason why he left for London. He married a wife whose temperament and tastes were entirely different from his own. He chose to go to London but still tried to carry out his responsibilities as a good father by sending money back home, and he did so because of his hopes for Judith. However, he only achieved opposite of what he wanted. The money turns Judith into a spoilt child, which brings destruction to his hopes for the family. Faced with two unthinking women, 
he hasn't much to say to them. "I was wrong to come-mistakes, mistakes. But I can't go back. That's hate, anger" (Bond, 1987, p. 55). He regards himself as a responsible father, but he fails to achieve a harmonious relationship with his daughter. The long awaited family reunion only provides a chance for both of them to express their anger and hate toward each other. This is the second ethical confusion Shakespeare experiences. He never enjoys domestic bliss.

The suffering caused by the loss of his creativity as a writer is another important ethical confusion that tortures Shakespeare. When the curtain goes up, we see him entering his garden, "he carries a sheet of paper" (Bond, 1987, p. 15). This opening prompts associative cues in the audience. Because the audience identifies Shakespeare foremost as a writer, it may assume that the sheet of paper he is holding is a manuscript of a play he's working on. Bond uses the familiarity of this image to engage the audience's emotional response: the piece of paper may turn out to be a play or poem. Since Shakespeare is for all time, by extension, the paper embodies everything that makes Shakespeare timeless: the artistry of his language, the humanity he expresses, and his popular appeal that seem to transcend time, place, class or ethnicity. When Combe comes to visit, the sheet of paper takes on a different form, quite unexpectedly. It becomes a legal document which represents a contractual relationship between two landlords and recalls that the source of Shakespeare's wealth is his investments in land which bring him money from the work of tenant farmers. His image of a self-interested, shrewd, and socially conservative businessman in a socio-economic context deconstructs his supposed image of a humane and morally-engaged playwright. Spencer writes: "We are disappointed" (Spencer, 1992, p. 50). So in the audience's mind it marks the end of Shakespeare's imaginative creativity in writing. It also marks the end of Shakespeare's imaginative life - he is searching for security for his final years, having no interest in writing any more!

The images of Shakespeare as both a writer and a businessman not only keep battling with each other in the minds of the audience, they are also battling with each other in Shakespeare's own mind. In Scene Four, Ben Jonson comes to bring Shakespeare the news that the Globe Theatre has burned down. They had a drink and talk in a tavern. Being asked what he is writing, Shakespeare answers he has written nothing new. The half-drunken Jonson banters with him: "Your recent stuff has been pretty peculiar. ... You're being sapped. I think you're dying. What a laugh! Are you getting hollow?" (Bond, 1987, p. 46) Jonson's sarcasm provokes Shakespeare into self-questioning. His silence in response to Jonson's comments most of the time is an implicit admission that his former self, when he had the same fighting spirit as Jonson, is just a by-gone. On the way back home, he is overcome with self-pity. He starts to repeat the same question and sighs deeply:

"Was anything done? Was anything done? I sit in a wound as large as a valley. The sides are smooth and cold and grey. I sit at the bottom and cry at my own death." (Bond, 1987, p. 57)

The deconstruction of the sheet of paper is the deconstruction of Shakespeare as a writer, an identity which is of essential importance to him. His great contribution to humanity as a writer is now being denied him. The embarrassment that results is shared by both the audience and Shakespeare himself. Being unable to write anything new of any value, Shakespeare even has doubts about what he has already written and enters the deepest ethical confusion in which he sees no meaning for the rest of his life. And it is here that it is hinted that he has thoughts of committing suicide. So, in this scene, Bond puts forward the society and social codes which were really at work behind the myth of Shakespeare. He commits suicide after the meeting with Jonson.

If his greed gets the better of his humanity, if family cannot offer him solace, if Shakespeare is no longer a writer, he is no longer truly Shakespeare. The three ethical lines form an inextricable ethical knot for him. Since he has no ability to handle the resulting psychological confusion, he sees death as a valid way of releasing himself from the torture of his ethical dilemma. Through examining the ethical dilemma in which he is trapped, it ceases to be hard to accept his choice of suicide. Bingo is not a parody of Shakespeare, but a vivid old Shakespeare portrayed in depth by Edward Bond.

\section{Reflection on the Alienation Effect of Bingo}

Without doubt the most extraordinary writing strategy of Bingo is that Bond brings Shakespeare down from the position of a saint to a secular person. This is the main reason that the play has aroused so many disputes and experienced such reversals of fortune. "Our comfortable natural haziness about Shakespeare is destroyed by Bond" (Worthen, 1975, p. 476). When the play shows Shakespeare in a different light, the audience is shocked. That is to say Bond's strategy in writing this historical play has achieved the "alienation effect" (Note 3) first developed by the German playwright Bertolt Brecht (1898-1956). "The term is rooted in the Russian Formalist notion of the device of making strange, which literary critic Viktor Shklovsky claims is the essence of all art" (Shklovsky, 1991, p. 145). According to Brecht, the alienation effect is achieved by the way that 
"The artist never acts as if there were a fourth wall besides the three surrounding him. ... The audience can no longer have the illusion of being the unseen spectator at an event which is really taking place. It prevents the audience from losing itself passively and completely in the character created by the actor, and which consequently leads the audience to be a consciously critical observer." (Willett, 1964, p. 91)

In Bingo, what the audience feels most familiar about Shakespeare has been de-familiarized by Bond. However, he doesn't de-familiarize him purely out of some purpose and awful randomness. History shows that Shakespeare isn't a man with a serene final period and the soul of genius, but a man with financial commitments. Such commitments have nothing to do with his being a genius, apart from his ability to perceive them; they have a good deal to do with survival and security in the kind of society of which he is a part. He is a man living with the same ethical paradoxes as every one else.

Bond has made audiences uncomfortable by creating two facts that cannot be reconciled in any traditional way. This kind of dissonance will generate discomfort and prompt the audience to take a more active role in the interpretive process. The burden of interpretation is now on the audience. They must move beyond what is comfortable to find an interpretive solution. In his "Letter to Michael Fuller," Bond presents his particular interpretive challenge: "The most important work in the theatre is always the work of the audience" (Bond, 1997, p. 19). If the audience chooses to interpret Shakespeare's suicide sentimentally, viewing him as one who doesn't want to join other greedy men of his time and so choose suicide, Shakespeare is still the great man of legend, the figure of myth and art, a cultural hero. If they choose to interpret Shakespeare's suicide rationally, Shakespeare becomes a little man, a coward, a figure of business and politics and a liar whose writing has played with people. Yet instead of providing cues towards one interpretation or the other, Bond presents his audience with a piece of blank paper on which to draw their own conclusions. How audiences choose to interpret Shakespeare's suicide determines their understanding of Shakespeare, their understanding of history and their understanding of the play And by revealing their own interpretive biases, it will potentially reveal audiences' sense of themselves and what they value.

\section{Conclusion}

When interviewed by Heinz Stoll Karl in 1976, Bond said, "To show our society that is irrational and therefore dangerous - and that it maintains itself by denigrating and corrupting human beings - that is what Bingo is about" (Karl, 1976, p. 418).To view it ethically, Shakespeare's suicide is not his own personal tragedy, but the tragedy of a period of British history in which Britain was moving from a feudal economy to a capitalist one. During this period, the true Shakespeare might not have committed suicide as Bond portrays, but there were certainly many other "ShakespeareS" who chose this way to unlace their ethical knots. "The more disputes a work receives, the more classical it is." (Note 2) The great German poet Goethe once wrote about "Shakespeare und kein Ende (the open-endedness of Shakespeare)!" He means Shakespeare's plays deserve to be the subject of endless re-interpretation and debate. But today, this endless re-interpretation is shifting from the plays to Shakespeare himself. The Romeo-like young Shakespeare in Tom Stoppard's Skakespeare in Love and the Shylock-like middle aged Shakespeare in Robert Farquharson Sharp's Biographical Sketches of Great Writers from Shakespeare to Tennyson are two examples. Bond's King Lear-like aged Shakespeare in Bingo is another example, and it too is deservedly the subject of endless re-interpretation and debate.

\section{Notes}

Note 1. The Literary Mind and the Carving of Dragons, also known as Wen Xin Diao Long in Chinese, is the first theoretical book dealing with aesthetics and the systematic study of literature in Chinese history. It was written by Liu Xie. He composed the work in fifty chapters. Vincent Yu-chung Shih from Columbia University translated the full book into English in 1959. The Chinese scholar Yang Xianyi translated five chapters into English in 1962, and Siu-kit Wong from the Chinese University of Hongkong translated one chapter.

Note 2. Cited from Mo Yan's speech at Stockholm University given on December 9, 2012.

Note 3. Brecht's coinage of this term was "Verfremdungseffekt" in German. John Willett's 1964 English translation in 1935 called it "alienation effect." Lemon and Reis's 1965 English translation from the Russian critic Shklovsky's 1917 term for it called it "de-familiarization." More lately, it has also been called "distancing effect" and "estrangement effect".

\section{References}

Bond, E. (1987). Plays: Three. Suffolk: Methuen.

Bond, E. (1997). Letter to Michael Fuller, 13 January, 1988. In I. Stuart (Ed.), Letters I (pp. 1-25). Amsteldijk: Harwood Academic Publishers. 
Brown, P. (2012, February 23). Bingo: Review. Retrieved from http://www.londontheatre.co.uk/londontheatre/reviews/bingo2012.htm

Gordon, G., \& Bond, E. (1966). Edward Bond: An interview by Giles Gordon. The Transatlantic Review, $1996(22), 7-15$.

Guo, Y.-D, Xie, S.-W., Shang, X.-F., \& Ding, C.-L. (2000). 中国古典文学研究史 [The History of Ancient Chinese Literature Study]. Beijing: Zhonghua Book Company.

Jin, Y. (1994). 金庸作品集·神雕侠侣（一） [Collected Works of Jin Yong·Divine Eagle, Gallant Knight] (Vol. 1, SDX Joint edition). Beijing: SDX Joint Publishing Company.

Karl, H. S., Bond, E., \& Wesker, A. (1976). Interviews with Edward Bond and Arnold Wesker Author(s). Twentieth Century Literature, 22(4), 411-432. http://dx.doi.org/10.2307/440583

Liu, X. (2011). 文心雕龙 [The Literary Mind and the Carving of Dragons]. Hangzhou: Zhejiang Acient Books Publishing House.

Nie, Z.-Z. (2010). Ethical Literary Criticism: Its Fundaments and Terms. Foreign Literature Studies, 2010(10), $12-22$.

Nightingale, B. (1973). The Bourgeois Bard. New Statesman, November 23.

Shklovsky, V. (1991). Art as Device. In G. L. Bruns (Ed.), \& B. Sher (Trans.), The Theory of Prose. Bloomington, IL: Dalkey Archive Press.

Spencer, J. S. (1992). Dramatic strategies in the plays of Edward Bond. Cambridge: Cambridge UP.

Trussler, S. (1976). Edward Bond. Essex: Longman.

Willett, J. (Ed. \& Trans.). (1964). Brecht on Theatre: The Development of an Aesthetic. London: Methuen.

Worthen, J. (1975). Endings and Beginnings: Edward Bond and the Shock of Recognition. Educational Theatre Journal, 27(4), 466-479. http://dx.doi.org/10.2307/3206380

\section{Copyrights}

Copyright for this article is retained by the author(s), with first publication rights granted to the journal.

This is an open-access article distributed under the terms and conditions of the Creative Commons Attribution license (http://creativecommons.org/licenses/by/3.0/). 